\title{
GMR
}

\section{Controversial results of therapy with mesenchymal stem cells in the acute phase of canine distemper disease}

\author{
A.O. Pinheiro ${ }^{1}$, M.T. Cardoso ${ }^{2}$, A.S. Vidane ${ }^{1}$, J.B. Casals ${ }^{1}$, D. Passarelli ${ }^{2}$, \\ A.L.F. Alencar ${ }^{2}$, R.L.M. Sousa ${ }^{2}$, P. Fantinato-Neto ${ }^{1}$, V.C. Oliveira', \\ V.M. Lara ${ }^{2}$ and C.E. Ambrósio ${ }^{1}$ \\ ${ }^{1}$ Laboratório de Anatomia de Animais Domésticos e Silvestres, \\ Departamento de Cirurgia, Faculdade de Medicina Veterinária e Saúde Animal, \\ Universidade de São Paulo, São Paulo, SP, Brasil \\ ${ }^{2}$ Departamento de Medicina Veterinária, \\ Faculdade de Zootecnia e Engenharia de Alimentos, \\ Universidade de São Paulo, Pirassununga, SP, Brasil \\ Corresponding author: C.E. Ambrósio \\ E-mail: ceambrosio@usp.br
}

Genet. Mol. Res. 15 (2): gmr.15028310

Received December 21, 2015

Accepted February 11, 2016

Published May 23, 2016

DOI http://dx.doi.org/10.4238/gmr.15028310

\begin{abstract}
Distemper disease is an infectious disease reported in several species of domestic and wild carnivores. The high mortality rate of animals infected with canine distemper virus (CDV) treated with currently available therapies has driven the study of new efficacious treatments. Mesenchymal stem cell (MSC)-based therapy is a promising therapeutic option for many degenerative, hereditary, and inflammatory diseases. Therefore, the aim of this study was to characterize stem cells derived from the canine fetal olfactory epithelium and to assess the systemic response of animals infected with CDV to symptomatic therapy and treatment with MSCs. Eight domestic mongrel dogs $(\mathrm{N}=8)$ were divided into two groups: support
\end{abstract}


group $(\mathrm{SG})(\mathrm{N}=5)$ and support group + cell therapy (SGCT) $(\mathrm{N}=3)$, which were monitored over 15 days. Blood samples were collected on days $0,6,9,12$, and 15 to assess blood count and serum biochemistry (urea, creatinine, alanine transferase, alkaline phosphatase, gammaglutamyl transferase, total protein, albumin, and globulin), and urine samples were obtained on days 0 and 15 for urinary evaluation (urine I). The results showed a high mortality rate $(\mathrm{SG}=4$ and $\mathrm{SGCT}=2)$, providing inadequate data on the clinical course of CDV infection. MSC therapy resulted in no significant improvement when administered during the acute phase of canine distemper disease, and a prevalence of animals with high mortality rate was found in both groups due to the severity of symptoms.

Key words: Canine distemper; Infectious; Stem cells; Treatment; Virus

\section{INTRODUCTION}

Canine distemper virus (CDV) is an RNA virus of the genus morbillivirus, which is distributed worldwide and affects several species of domestic and wild carnivores. It affects members of the Canidae, Felidae, Mustelidae, Viverridae, Procyonidae, and Cercopithecidae (Qui et al., 2011; Cottrell et al., 2013; Lempp et al., 2014). Infection with CDV results in acute, subacute, or chronic clinical presentation, which primarily affects the respiratory, gastrointestinal, and nervous systems (Mangia and Paes, 2008; Martella et al., 2008; Sonne et al., 2009; Carvalho et al., 2012; Lempp et al., 2014). Conventional treatment of CDV infection is based upon symptomatic and supportive therapy (McCandlish, 2001) and has not been very effective. Numerous antiviral drugs used in in vitro and in vivo studies have shown promise for the treatment of CDV infection; however, at present, no effective and safe antiviral treatment exists for dogs infected with CDV (Elia et al., 2008; Mangia et al., 2014; Trejo-Avila et al., 2014). Due to the lack of effective treatments and the severity of clinical signs, which often progress to irreversible neurological sequelae, euthanasia is often a frequent indication for animals with canine distemper (Ueda et al., 2008).

Stem cells are undifferentiated cells that possess the characteristics of self-renewal and differentiation (Dominici et al., 2006; Bydlowski et al., 2009; Nery et al., 2013). Basal cells in the olfactory epithelium are considered to be stem cells owing to their pluripotent ability to generate support cells or olfactory cells, and may be characterized as mesenchymal stem cells (MSCs) (Alves, 2009, unpublished). MSCs have low immunogenicity, potential immunomodulatory effects, and therapeutic promise owing to their efficient inhibition of growth and activation of various cellular components of innate and adaptive immunity, which reduce inflammation and promote tissue repair in the treatment of inflammatory diseases (Marti et al., 2011; Sánchez-Berná et al., 2015).

Due to the lack of effective agents to treat canine distemper, and the immunomodulatory role of MSCs in the control and treatment of inflammatory diseases, the aim of this study was to characterize stem cells derived from the canine fetal olfactory epithelium and to assess their application in dogs infected with CDV in the acute phase of disease. 


\section{MATERIAL AND METHODS}

\section{Isolation and culture of fetal canine olfactory epithelial stem cells}

The study protocol was approved by the research ethics committee (13.1.1757.74.6) of the Faculty of Animal Science and Food Engineering, University of São Paulo, Brazil. Twenty canine fetuses in the last third of gestation were collected from the uteri of domestic dogs of mixed breed. Fragments of the olfactory epithelium were washed and degraded with 1 mL Tryple Express $0.25 \%$ (Invitrogen, Carlsbad, USA). The cells were cultured on plates with Dulbecco's modified Eagle medium/nutrient mixture F-12 (DMEM/F12) medium (Invitrogen, Carlsbad, USA) supplemented with $15 \%$ fetal bovine serum, $1 \%$ non-essential amino acids, $1 \% \mathrm{~L}$-glutamine, and $1 \%$ penicillin/streptomycin, and incubated at $37^{\circ} \mathrm{C}$ with $5 \% \mathrm{CO}^{2}$ and relative humidity close to $80 \%$.

\section{Cryopreservation}

Cells were cultured at a density of $1 \times 10^{5}$ cells in passage one and were then frozen. DMEM/F-12 medium, supplemented with $45 \%$ fetal bovine serum and $10 \%$ dimethyl sulfoxide, was used. The cells were frozen over $24 \mathrm{~h}$ at $-80^{\circ} \mathrm{C}$ and were then transferred and stored in liquid nitrogen until use.

\section{Growth curve}

Cells at a density of $3 \times 10^{4}$ (passage one) were used to determine the cell doubling time, by counting every 2 days and replating at the same density. Similar procedures were performed at each subsequent passage until passage eight. The population doubling time was calculated in each passage as $\mathrm{Ct} / \mathrm{Cd}$, where $\mathrm{Ct}$ represents culture time between passage $\mathrm{n}$ and passage $\mathrm{n}+1$, and $\mathrm{Cd}$ represents the cell doubling. $\mathrm{Cd}$ was calculated using the formula $\mathrm{Cd}=$ $\ln (\mathrm{nf} / \mathrm{ni}) / \ln 2$, where $\mathrm{nf}$ represents harvested cells and ni represents seeded cells.

\section{Colony forming assays}

Colonies of $1 \times 10^{3}$ cells of each primary culture were plated on DMEN/F12 medium. After 11 days, the growth medium was discarded, and adherent cells were fixed in $4 \%$ paraformaldehyde (Sigma, St. Louis, MO, USA) and stained for 15 min using 0.1\% Giemsa.

\section{In vitro differentiation assays}

To promote osteogenic and adipogenic differentiation, $1 \times 10^{5}$ cells were cultured in StemXVivo ${ }^{\text {TM }}$ Human/Mouse Osteogenic/Adipogenic Base Media (R\&D, Minneapolis, USA) supplemented with penicillin-streptomyciun. When the osteogenic and adipogenic cells had reached approximately 70 and $100 \%$ confluence, respectively, differentiation medium was added (R\&D, Minneapolis, USA). After 21 days, the cells were fixed with 4\% paraformaldehyde and stained by Alizarin red and Sudan Black, respectively. For chondrogenic differentiation, $2.5 \mathrm{x}$ $10^{5}$ cells were placed in Falcon tubes with $5 \mathrm{~mL}$ StemXVivoTM Human/Mouse Chondrogenic medium (R\&D) supplemented with penicillin-streptomyciun. After 3 days, the cells were 
resuspended in $2 \mathrm{~mL}$ differentiation medium (R\&D). The pellets were maintained in medium containing a differentiator for 21 days and were then fixed, stained, and analyzed using Alcian Blue and Masson's trichrome staining. For neurogenic differentiation, 3 x $10^{5}$ cells were placed on microscope slides. After reaching $80 \%$ confluence, $0.5 \mu \mathrm{L}$ monoetilglicerol (Sigma) was added to each well. After $24 \mathrm{~h}$, cells were fixed for immunocytochemical analysis.

\section{Immunocytochemical analysis}

Cells were cultured and prepared for immunocytochemical analysis as previously described (Sampaio et al., 2015) using a panel of mesenchymal (CD73, CD90, and CD105), hematopoietic (CD34, CD45, and CD79) (Santa Cruz Biotechnology, Santa Cruz, CA, USA), and neuronal markers [GFAP(GF5), nestin (SP103), and beta III Tubulin] (Abcam, Cambridge, UK) with the respective secondary antibody (Abcam; Alexa Flúor 488 Invitrogen, Carlsbad, CA, USA).

\section{Teratoma formation assays}

Teratoma formation assays were performed by administering $3 \times 10^{5}$ mesenchymal cells (passage 3 ) via intramuscular (i.m.), subcutaneous (s.c.), or intraperitoneal (i.p.) injection to two immunodeficient (BALB/c-nude) mice, with physiologic saline solution used as a negative control in one mouse. After 60 days, the animals were euthanized in a gas chamber. Thick tissues were stained with hematoxylin and eosin.

\section{Pre-clinical test}

For pre-clinical testing, a double-blind randomized trial was performed using eight dogs without distinguishing criteria of gender and breed and vaccination protocols inadequate or unvaccinated, based on clinical and neurological findings (Table 1, Figure 1). CDV positivity was confirmed by RT-PCR. Animals were subdivided into two groups: support group (SG) $(\mathrm{N}=5)$ and support group + cell therapy $(\mathrm{SGCT})(\mathrm{N}=3)$. The animals were monitored for 15 days and received symptomatic treatment according to systemic and neurology clinical presentation. Animals were subjected to clinical evaluations every 3 days, during which physical and neurological examinations were performed and samples were collected for laboratory analyses.

\section{RT-PCR assay}

On the first day (day 0), blood and urine samples were collected and stored at $-80^{\circ} \mathrm{C}$ until processing. RNA was extracted from $300 \mu \mathrm{L}$ of urine or blood using the TRIzol ${ }^{\circledR}$ method (Life Technologies, USA), according to the manufacturer instructions. The commercial vaccine Nobivac $^{\circledR}$ Puppy DP (MSD Animal Health, New York, NY, USA) containing live attenuated virus from the strain Onderstepoort was used as a positive control and nuclease-free water was used as a negative control.

Primers were selected to amplify gene N of CDV by hemi-nested RT-PCR, as described by Di Francesco et al. (2012). Suspected clinical cases were confirmed by amplifying a 180-bp fragment of the $\mathrm{N}$ gene of the Onderstepoort strain by hemi-nested RT-PCR (Table 2). 
Table 1. Number of animals with systemic clinical and neurological signs by treatment group.

\begin{tabular}{|c|c|c|}
\hline Sign & Suport group & Suport group + cellular therapy \\
\hline Abdominal pustules & $1(20 \%)$ & \\
\hline Ataxia & $5(100 \%)$ & $2(66.6 \%)$ \\
\hline Alterations in cranial nerves & $2(40 \%)$ & $2(66.6 \%)$ \\
\hline Apathy & $2(40 \%)$ & \\
\hline Cough & $2(40 \%)$ & \\
\hline Decreased proprioception & $1(20 \%)$ & \\
\hline Decubitus permanent & & $1(33.3 \%)$ \\
\hline Deficits of locomotion & $4(80 \%)$ & $3(100 \%)$ \\
\hline Diarrhea & $1(20 \%)$ & \\
\hline Dyspnea & $1(20 \%)$ & \\
\hline Emesis & & $3(100 \%)$ \\
\hline Fatigue & $3(60 \%)$ & \\
\hline Head deviation & $1(20 \%)$ & \\
\hline Hipodipsia & $1(20 \%)$ & \\
\hline Hyporexia & $3(60 \%)$ & $1(33.3 \%)$ \\
\hline Hypermetria & $1(20 \%)$ & \\
\hline Hyperexcitability & $1(20 \%)$ & \\
\hline Hyperkeratosis of digital region & $1(20 \%)$ & \\
\hline Myoclonus & $2(40 \%)$ & $2(66.6 \%)$ \\
\hline \multicolumn{3}{|l|}{ Muscle atrophy } \\
\hline \multicolumn{3}{|l|}{ Night crying } \\
\hline Nystagmus & $1(20 \%)$ & \\
\hline Nasal secretion & $2(40 \%)$ & $1(33.3 \%)$ \\
\hline Paresis & $1(20 \%)$ & $2(66.6 \%)$ \\
\hline Scaly skin & $1(20 \%)$ & \\
\hline Secretion ocular & $3(60 \%)$ & $1(33.3 \%)$ \\
\hline Shake of the head & $1(20 \%)$ & \\
\hline Sialorrhoea & & $1(33.3 \%)$ \\
\hline Spasticity members & & $1(33.3 \%)$ \\
\hline Urinary incontinence & & $1(33.3 \%)$ \\
\hline Tremors & $2(40 \%)$ & \\
\hline Trismus & & $1(33.3 \%)$ \\
\hline
\end{tabular}

Walk in circles $1(20 \%)$.

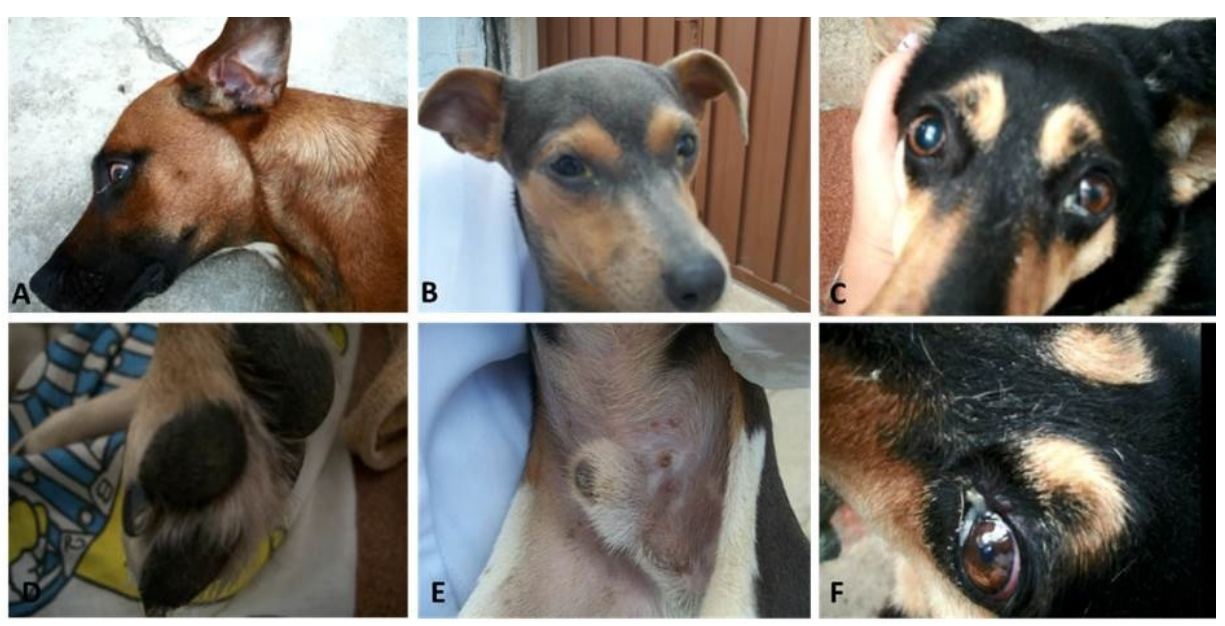

Figure 1. Photographs showing the main clinical signs observed in animals during physical examination: A. animal presenting neurological dysfunctions, including ataxia, lockjaw, and myoclonus, and systemic signs such as ejection episcleral vessels; B. bilateral mucopurulent ocular discharge; C. unilateral purulent ocular discharge anisocoria; D. hyperkeratosis cushions podais; E. presence of pustules in the abdominal region; F. unilateral ocular purulent discharge and anisocoria. 
Table 2. Primers used for hemi-nested RT-PCR.

\begin{tabular}{l|l|c|c}
\hline Primer & Sequence $\left(5^{\prime}-3^{\prime}\right)$ & Gene & Product (bp) \\
\cline { 1 - 2 } C2 & AAGATCTGCCGGCAAAGTAAGCTCTG & N & 350 \\
\cline { 1 - 2 } REV1441 & CGGTCATCGTCGTTTCCATC & & N \\
\hline FW1261 & CACTCAGAAAGATCCGAAGTCA & N & 180 \\
\hline
\end{tabular}

Source: Di Francesco et al. (2012).

\section{Laboratory exams}

Blood samples were collected on days $0,6,9,12$, and 15 by venous puncture and packaged in tubes containing 7.5\% EDTA. Total cell counts were determined using automated hematology equipment (BC Vet in 2800, Mindray, China). Differential leukocyte counts were obtained from blood smears subjected to Rosenfeld staining. Biochemical analyses were performed with samples collected on days 0 and 15 , which were screened to determine serum urea, creatinine, alanine transferase, alkaline phosphatase, gamma-glutamyl transferase, total protein, albumin, and globulins with an automated biochemical analyzer (BS 120, Mindray, China). Urinalysis type I was performed with urine samples collected on days 0 and 15 using an urethrovesical probe. Physical examination involved analyzing the color, odor, appearance, and density of urine. Chemical examination determined the levels of urobilinogen, glucose, ketones, bilirubin, protein, the $\mathrm{pH}$, and the presence of occult blood. For the sediment analysis, the urine was centrifuged, and a drop of the sediment was used for microscopic assessment.

\section{Treatment}

All animals received symptomatic treatment based on their clinical presentation according to Table 3. On day 3, animals were randomized and inoculation with $1.0 \times 10^{6} / \mathrm{kg}$ stem cells derived from the fetal olfactory epithelium or saline solution in a single intravenous injection.

\begin{tabular}{|c|c|c|c|c|}
\hline & Active Principle & Dose & Interval (h) & Route of administration \\
\hline \multirow[t]{2}{*}{ Antiemetics } & Metoclopramide hydrochloride & $0.5 \mathrm{mg} / \mathrm{kg}$ & 8 & s.c. \\
\hline & Ondansetron & $0.22 \mathrm{mg} / \mathrm{kg}$ & 8 & i.v. \\
\hline \multirow[t]{3}{*}{ Gastric mucosa protectors } & Ranitidine & $2 \mathrm{mg} / \mathrm{kg}$ & 12 & s.c. \\
\hline & \begin{tabular}{|l|} 
Cimetidine \\
\end{tabular} & $5 \mathrm{mg} / \mathrm{kg}$ & 8 & s.c. \\
\hline & Omeprazol & $1.5 \mathrm{mg} / \mathrm{kg}$ & 24 & p.o. \\
\hline Antipyretic & Dipyrone sodium & $25 \mathrm{mg} / \mathrm{kg}$ & 8 & s.c. \\
\hline \multirow[t]{4}{*}{ Vitamin complex } & Vitamins A & $400 \mathrm{IU} / \mathrm{kg}$ & 24 & p.o. \\
\hline & B complex & $250 \mathrm{mcg} / \mathrm{kg}$ & 24 & i.m. \\
\hline & Vitamin C & $250 \mathrm{mg} /$ animal & 24 & p.o. \\
\hline & Vitamin E & $5 \mathrm{mg} / \mathrm{kg}$ & 24 & p.o. \\
\hline Systemic antimicrobials & Sulfametoxazol + Trimetoprima & $25 \mathrm{mg} / \mathrm{kg}$ & 12 & s.c. \\
\hline
\end{tabular}

s.c. $=$ subcutaneous; $i . v .=$ intravenous; $p . o .=$ orally; $i . m .=$ intramuscular.

\section{Statistical analysis}

Data were analyzed using the statistical program Statistical Analysis System (SAS, 9.3) with prior verification of normal errors by the Shapiro-Wilk test. Original data were submitted to ANOVA. Repeated measures was used to factor in the different sampling times. The probabilities of interactions with time were determined by the Greenhouse-Geisse test 
using the REPEATED command generated by the MIXED procedure (SAS PROC MIXED). Analyses were performed only for the time when the interaction between time and treatment was significant. In all statistical analyzes, the significance level was $5 \%$.

\section{RESULTS}

\section{Characterization of cells}

All cells were grown under controlled conditions $\left(38.5^{\circ} \mathrm{C}\right.$ and $\left.5 \% \mathrm{CO}_{2}\right)$ and the presence of adherent cells was observed after $24 \mathrm{~h}$ in culture. The cells presented fibroblastlike morphology (Figure 2A-B). Following cryopreservation, cells were $67 \%$ viable.
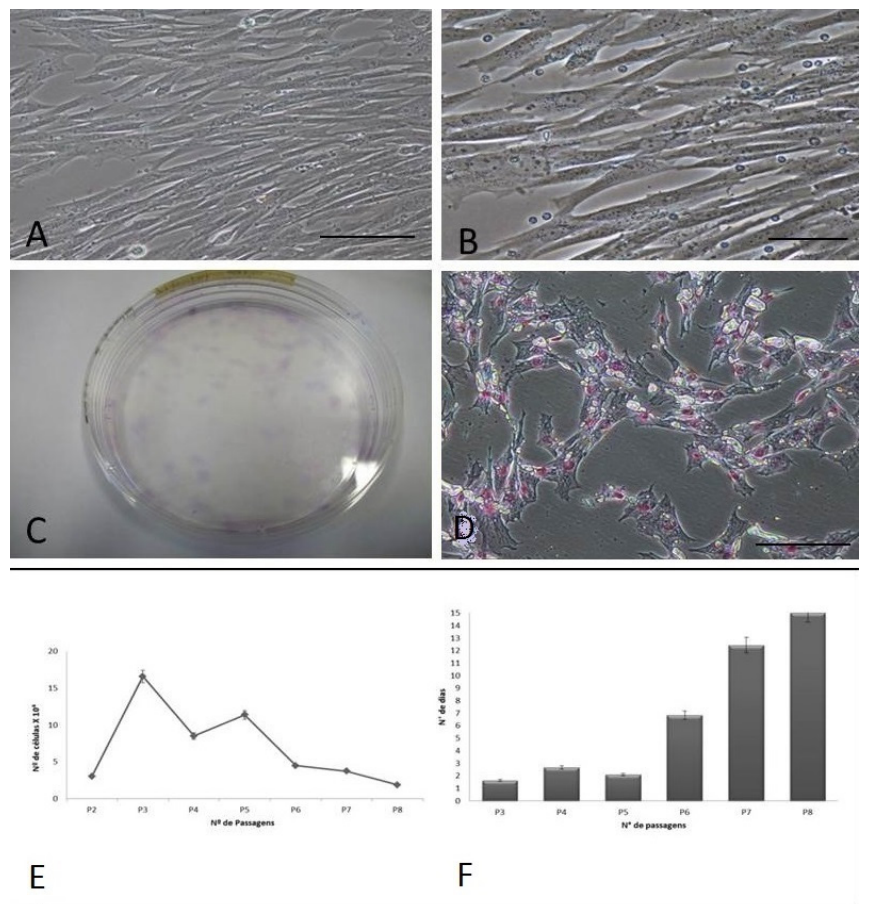

Figure 2. Photomicrograph of plates showing cultured mesenchymal stem cells: A. passage P0, 5 days after cultivation 20X (bar: $100 \mu \mathrm{m}$ ); B. passage P0, 5 days after cultivation 40X (bar: $50 \mu \mathrm{m}$ ); C. and D. colony forming units obtained after cultured mesenchymal cells derived from canine fetal olfactory epithelium were subjected to Giemsa staining; E. very rapid growth of cells during the first two passages and a back drop with a stationary trend. F. Graph showing the number of days required for cell doubling. Bars: A. $100 \mu \mathrm{m}(20 \mathrm{X})$; B. $50 \mu \mathrm{m}(40 \mathrm{X})$; D. $50 \mu \mathrm{m}(20 \mathrm{X})$.

Cells were maintained over an 11-day period until colony formation was observed. Colonies were counted on three plates and an average of 118.3 colonies was found (Figure 2C-D).

After successive passages, the growth curve showed accelerated growth at the beginning of the culture period (with a predominance of proliferation in the third passage) with proliferation gradually decreasing to the eighth passage (Figure 2E). The doubling time was consistent over subsequent passages. The gradual decrease in the rate of proliferation is consistent with increasing passages (Figure 2F). 
Morphological changes were observed in cells cultured in adipogenic differentiation media after 21 days, with the formation of intracytoplasmic vacuoles, observed by stained with Sudan lack (Figure 3A-D). After 21 days in osteogenic differentiation media, cells exhibited extracellular mineral deposition when stained with Alizarin Red (Figure 3E-H). Collagen fibers were stained with Masson's trichrome and Alcian Blue at 21 days of culture (Figure 3I-L). After $24 \mathrm{~h}$ in neurogenic differentiation media, cells showed morphological changes of cells with grouping neuro-formed beads (Figure 3M-P).
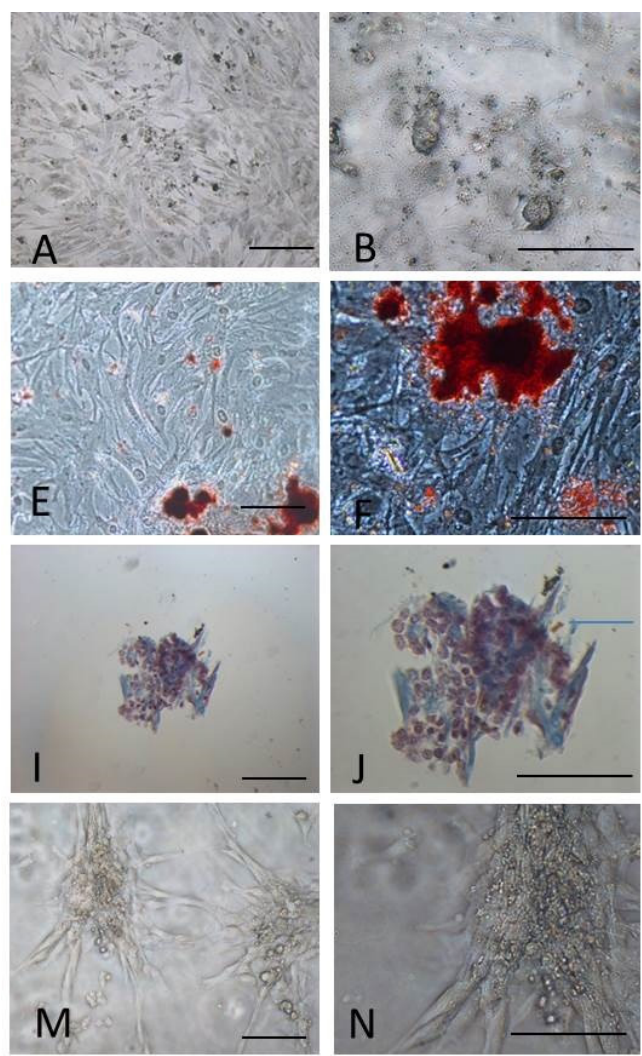
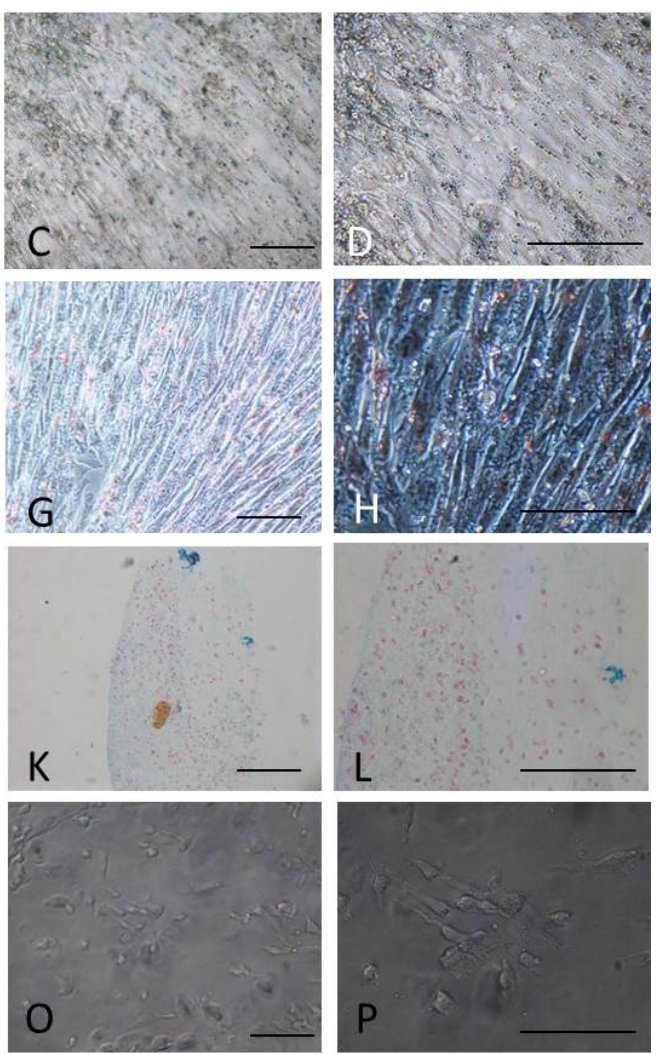

Figure 3. Differentiated plates; A. B. photomicrographs of cells undergoing adipogenic differentiation stained with Sudan Black. C. D. culture of undifferentiated cells; E. F. photomicrographs of cells undergoing osteogenic differentiation stained with Alizarin Red; G. H. culture of undifferentiated cells; I. J. photomicrographs of cells undergoing chondrogenic differentiation, collagen fibers subjected to Masson's trichrome staining are shown in blue; K. L. collagen fibers stained by Alcian Blue are shown in blue; M. N. photomicrographs of cells undergoing neurogenic differentiation. O. P. culture of undifferentiated cells. Bars: (A, C, E, G, I, K, M, N, and O) $50 \mu \mathrm{m}$ (20X); (B, D, F, H, J, and L) $20 \mu \mathrm{m}(40 \mathrm{X})$.

This cell lineage showed positive expression of mesenchymal markers, CD73, CD90 and CD105 (Figure 4A-C), negative expression of specific hematopoietic cell markers CD34, CD45, and CD79 (Figure 4D-F), positive expression of neuronal markers b tubulin, and negative expression of GFAP and nestin (Figure 4G-I). 

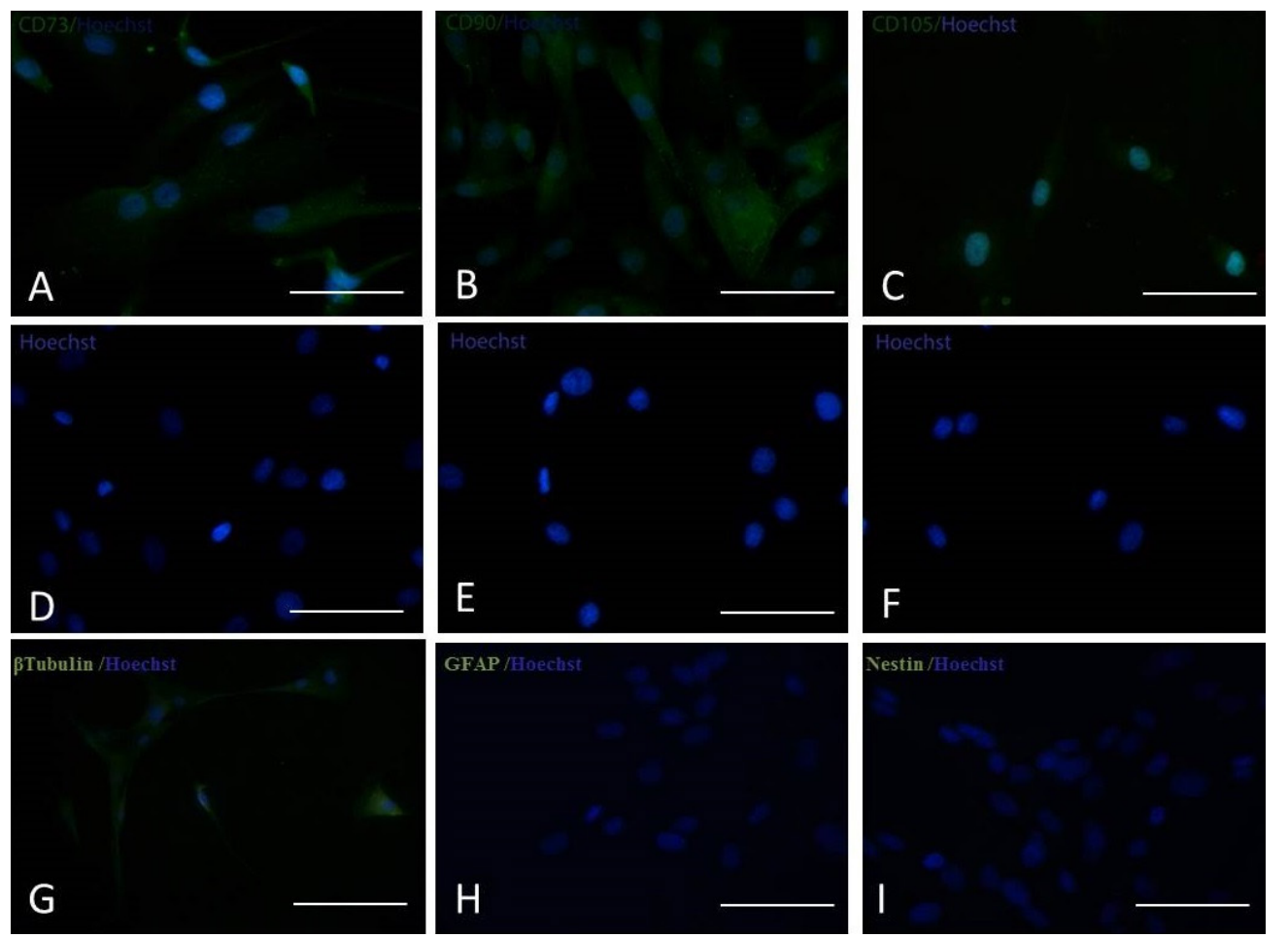

Figure 4. Photomicrographs of cells subjected to immunocytochemistry for mesenchymal, hematopoietic, and neural markers; A. positive staining for CD73; B. positive staining for CD90; C. positive staining for CD105; D. expression of negative marker CD34; E. negative staining for CD45; F. negative staining for CD79; G. positive staining for neuronal marker $\beta$ Tubulin; H. negative staining for GFAP; I. negative staining for nestin. Bars: (A, B, C, D, E, F, G, H, I) $50 \mu \mathrm{m}(40 \mathrm{X})$.

In the teratoma formation test, no teratomas were observed macroscopically at the inoculation points or in the internal organs. Histopathological analysis of muscle fragments, brain, lung, heart, liver, kidney, spleen, and intestine, revealed no morphological changes (Figure 5A-L).

\section{Pre-clinical test}

Using RT-PCR, $80 \%$ CDV positivity was observed in urine samples and 20\% CDV positivity was observed in the analyzed blood samples. Significant variance was recorded between groups in the levels of platelets, eosinophils, and lymphocytes. However, there was no significant variation over time. Significant variance was recorded for hematocrit and hemoglobin values over time. Hematologic values are shown in Tables 4 and 5. Biochemical analyses failed to show statistical differences between groups, collection days, or any interaction between days and groups. No significant differences were observed between the two groups in the urine, physical examinaton, chemical, and sediment parameters. Two SGCT animals presented with cloudy urine, which contained bacteria and white blood cells, indicative of bacterial cystitis. 


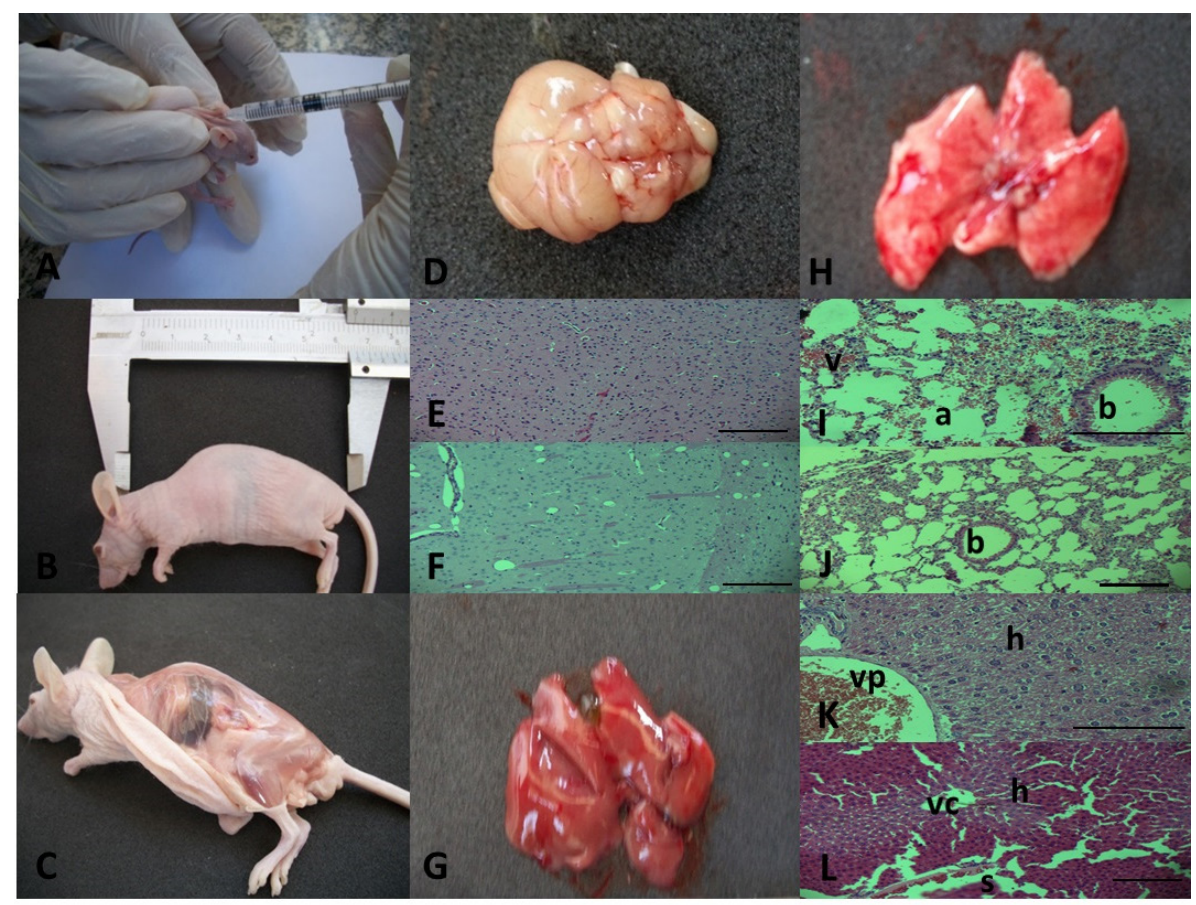

Figure 5. Photomicrographs showing control animals and stem cell inoculated animals; A. subcutaneous inoculation in the neck; B. BALB/c nude mouse; C. subcutaneous region of the application site. Photomicrographs of different organs (Crt: untreated; Inoc: stem cell inoculated D. macroscopic view of the brain; E. F. microscopic view of the brain from Crt animal; G. macroscopic view of the liver from Inoc animal; H. macroscopic view of the lung; I. microscopic observation of the Crt animal lung (v: vein; a: alveoli; b: bronchia); J. microscopic observation of the Inoc animal lung showing the alveoli, blood vessels, and bronchi (b: bronchi); K. microscopic observation of the liver from Crt animals (vp: portal vein; h: hepatocytes); L. microscopic observation of the liver showing the lumen of the vein and the hepatic parenchymal hepatocytes (vc: cav vein; h: hepatocytes; s: sinusoid). Bars: J. $100 \mu \mathrm{m}(5 \mathrm{X})$; F. I. and L. $100 \mu \mathrm{m}$ (10X); E. K. $100 \mu \mathrm{m}(20 \mathrm{X})$.

Table 4. Statistical differences between treatment groups.

\begin{tabular}{|c|c|c|c|c|}
\hline & \multicolumn{2}{|c|}{ SG } & \multicolumn{2}{|c|}{ SGCT } \\
\hline & Average & SD & Average & SD \\
\hline Red blood cells $\left(\times 10^{6} / \mu \mathrm{L}\right)$ & 4.86 & 0.99 & 5.45 & 0.55 \\
\hline Hemoglobin $(\mathrm{g} / \mathrm{dL})$ & 12.99 & 3.01 & 14.35 & 1.02 \\
\hline Hematocrit (\%) & 35.48 & 8.21 & 38.56 & 2.77 \\
\hline Reticulocyte (\%) & 0.24 & 0.78 & 0.00 & 0.00 \\
\hline $\mathrm{VCM}(\mathrm{fL})$ & 72.91 & 5.56 & 72.54 & 6.54 \\
\hline $\mathrm{HCM}(\mathrm{fL})$ & 26.62 & 2.39 & 26.46 & 2.71 \\
\hline CHCM (\%) & 36.61 & 1.60 & 36.55 & 1.37 \\
\hline Erythroblasts & 1.18 & 2.36 & 0.14 & 0.36 \\
\hline Platelets $\left(10^{3} / \mu \mathrm{L}\right)$ & $301,636.36^{*}$ & $206,040.91$ & $587,928.57^{*}$ & $376,874.69$ \\
\hline Leukocytes $\left(\times 10^{3} / \mu \mathrm{L}\right)$ & $14,815.38$ & $10,968.96$ & $12,280.00$ & $4,495.74$ \\
\hline Rod cells & 31.77 & 114.55 & 543.33 & 705.93 \\
\hline Segmented & $11,767.69^{*}$ & $8,960.37$ & $10,203.60^{*}$ & $3,798.11$ \\
\hline Eosinophils & $69.69^{*}$ & 102.15 & $224.60 *$ & 232.69 \\
\hline Lymphocytes & $1,497.23$ & $1,156.55$ & 780.73 & $1,183.28$ \\
\hline Basophils & 5.85 & 21.08 & 7.47 & 28.92 \\
\hline Monocytes & $1,443.15$ & $1,762.19$ & 964.93 & 432.48 \\
\hline
\end{tabular}

Statistics: Tukey test. *Smaller P values indicate a significant difference between groups. GS = group support; $\mathrm{SGTC}=$ group support + cell therapy; $\mathrm{SD}=$ standard deviation. 


\begin{tabular}{|c|c|c|c|c|c|c|c|c|c|c|}
\hline & \multicolumn{2}{|c|}{ Day 0} & \multicolumn{2}{|c|}{ Day 6} & \multicolumn{2}{|c|}{ Day 9} & \multicolumn{2}{|c|}{ Day 12} & \multicolumn{2}{|c|}{ Day 15} \\
\hline & Average & SD & Average & SD & Average & SD & Average & SD & Average & SD \\
\hline Red blood cells $\left(\mathrm{x} 10^{6} / \mu \mathrm{L}\right)$ & 4.37 & 1.04 & 4.91 & 0.58 & 5.51 & 0.41 & 5.79 & 0.47 & 5.58 & 0.81 \\
\hline Hemoglobin $(\mathrm{g} / \mathrm{dL})$ & $11.04^{\mathrm{c}}$ & 2.93 & $13.25^{\mathrm{bc}}$ & 0.54 & $14.43^{\mathrm{ab}}$ & 1.44 & $15.28^{\mathrm{a}}$ & 1.43 & $15.35^{\mathrm{a}}$ & 0.90 \\
\hline Hematocrit (\%) & $31.20^{\mathrm{c}}$ & 6.96 & $35.80^{\mathrm{bc}}$ & 2.35 & $39.38^{\mathrm{ab}}$ & 4.58 & $42.65^{\mathrm{a}}$ & 3.86 & $39.95^{\mathrm{ab}}$ & 2.37 \\
\hline $\begin{array}{l}\text { Reticulocytes (\%) } \\
\end{array}$ & 0.43 & 1.06 & 0.00 & 0.00 & 0.00 & 0.00 & 0.00 & 0.00 & 0.00 & 0.00 \\
\hline $\mathrm{VCM}(\mathrm{fL})$ & 70.22 & 4.07 & 73.52 & 6.19 & 71.75 & 6.92 & 74.08 & 7.76 & 74.63 & 6.49 \\
\hline HCM (fL) & 25.12 & 1.46 & 27.18 & 2.44 & 26.25 & 2.55 & 26.50 & 3.51 & 27.78 & 2.95 \\
\hline CHCM $(\%)$ & 35.84 & 1.31 & 37.17 & 1.22 & 36.68 & 1.30 & 35.75 & 1.46 & 37.28 & 1.93 \\
\hline Erytroblasts & 0.20 & 0.45 & 1.50 & 3.21 & 0.33 & 0.52 & 0.50 & 1.00 & 0.25 & 0.50 \\
\hline Platelets $\left(10^{3} / \mu \mathrm{L}\right)$ & $344,200.00$ & $292,961.94$ & $414,000.00$ & $339,865.27$ & $458,833.33$ & $274,705.96$ & $525,000.00$ & $358,902.96$ & $622,750.00$ & $544,293.04$ \\
\hline Leukocytes $\left(\mathrm{x} 10^{3} / \mu \mathrm{L}\right)$ & $14,712.50$ & $11,628.71$ & $12,016.67$ & 6772.12 & $15,433.33$ & 8627.55 & $12,175.00$ & 4320.78 & $11,425.00$ & 5653.54 \\
\hline Rod cells & 82.60 & 184.70 & 40.00 & 80.00 & 0.00 & 0.00 & 0.00 & 0,00 & 490.00 & 753.79 \\
\hline Segmented & $11,580.13$ & $\begin{array}{l}8632.94 \\
\end{array}$ & 9906.83 & 5847.65 & 12919.67 & 8027.12 & $\begin{array}{l}0.400 .25 \\
10,460\end{array}$ & 3966.62 & 8648.25 & 4665.03 \\
\hline $\begin{array}{l}\text { Segnented } \\
\text { Eosinophils }\end{array}$ & $\begin{array}{l}11,500.15 \\
85.38\end{array}$ & $\begin{array}{l}8032.94 \\
159.34\end{array}$ & $\begin{array}{l}990.83 \\
112.83\end{array}$ & $\frac{54 / 7.05}{115.28}$ & $\frac{1219.01}{267.17}$ & $\frac{827.12}{325.74}$ & $\frac{10,460.25}{241.50}$ & $\frac{390.02}{137.97}$ & $\frac{8068.25}{86.50}$ & $\frac{4005.03}{122.57}$ \\
\hline Lymphocytes & 1590.50 & 1736.92 & 976.67 & 1040.27 & 818.33 & 693.08 & 573.25 & 688.56 & 1347.00 & 1295.44 \\
\hline Rod cells & 0.00 & 0.00 & 0.00 & 0.00 & 12.67 & 31.03 & 0.00 & 0.00 & 28.00 & $\frac{1253.00}{56.00}$ \\
\hline Monocites & 1423.63 & 1992.36 & 1020.33 & 1108.10 & 1388.83 & 960.59 & 900.00 & 689.65 & 947.75 & 174.30 \\
\hline
\end{tabular}

Different lowercase letters in the same line represent statistically different values between days, regardless of the test used. $\mathrm{SD}=$ standard deviation. $\mathrm{CHCM}=$ Mean corpuscular hemoglobin concentration.

A high mortality rate was observed following the treatment and monitoring period, and was prevalent in both the SG and SGCT animals. In the SG animals, mortality during treatment was $80 \%$ and survival rate with complete recovery was $20 \%$. In SGCT animals, the mortality rate was $66.6 \%$ and the survival rate was $33.3 \%$, without significant clinical improvement.

\section{DISCUSSION}

Olfactory epithelial cells have been widely studied in human and animal randomized clinical studies involving the central nervous system (Granger et al., 2012). In a previous study, Alves et al. (2007) reported that the canine olfactory epithelium gives rise to a cell lineage that is responsible for cell renewal. These cells showed fibroblast-like morphology and adhered to the surface of the cell culture vessel. These findings are specific for MSCs and have also been reported by Bydlowski et al. (2009). Peak cell growth was achieved in the third passage and then then decreased in subsequent passages, as reported by Lockhart (1971) and Vidane et al. (2014). When cultured at low densities, these cells form clusters (colony forming units), which may be used to quantify the number of MSCs in various tissues after transplantation (Nardi and Meirelles, 2006).

In the present study, we showed that MSCs derived from the canine olfactory epithelium can be cryopreserved for long periods without depreciation of the self-renewal capacity, which is consistent with the findings of Edamura et al. (2014). Immunocytochemical analyses showed that the canine olfactory epithelium stained positive for mesenchymal specific markers CD105, CD73, and CD90 and negative for CD34, CD45, and CD79. Regarding neuronal markers, GFAP was used, which is the principal structural component of astrocytes in adult animals, nestin and B tubulin. These cells were positive for $\beta$ tubulin and nonspecific for GFAP and nestin. However, Alves (unpublished results) reported that all neuronal markers were expressed. Cells in the third passage were submitted to osteogenic, adipogenic, and chondrogenic differentiation. After 21 days, morphological changes were observed, which were consistent with osteogenic, adipogenic, and chondrogenic cells, similar to the findings in MSCs (Dominici et al., 2006; Alves, 2009 [unpublished findings]; Bydlowski et al., 2009; Wenceslau et al., 2011; Vidane et al., 2014).

No teratomas were observed in the carcinogenic potential assay, and similar findings were described by Vidane et al. (2014) and Wenceslau et al., (2011) in other MSC lineages.

Various antemortem tests can be used for the diagnosis of CDV infection in the 
laboratory; however, in some cases, definitive diagnosis remains uncertain (Curti et al., 2012). According to those authors, the chromatographic immunoassay kit used to detect the canine distemper antigen is not effective for diagnosis of the neurologic form of viral infection when compared to the detection of CDV due to neurological changes in the experimental animals. The results of hemi-nested RT-PCR are consistent with data obtained by Negrão et al. (2007) who reported $90.4 \%$ positivity of all analyzed samples and $70.4 \%$ positivity of blood samples. These data confirmed the high sensitivity of urine samples when compared to blood samples (Gebara et al., 2004; Negrão et al., 2007; Alcalde et al., 2013). According to McCandlish (2001), the clinical signs of CDV infection are variable and can be influenced by intrinsic and extrinsic factors such as age, physical condition, immune status, and the strain of virus involved.

Regarding blood parameters, previous studies have reported the presence of normocytic normochromic anemia (Mendonça et al., 2000), leukocytosis or leukopenia, and lymphopenia (Silva et al., 2005). The present data are consistent with normocytic normochromic anemia and neutrophilia in the early stages of treatment, and lymphopenia. Biochemical analyses are nonspecific in dogs with CDV according to McCandlish (2001). We found changes in liver function by way of hepatobiliary enzymes, which can be explained by the use of antimicrobials such as sulfamethoxazole/trimethoprim and their metabolism in the liver. During CDV infection, urinalysis results are nonspecific according to McCandlish (2001). In the present study urinalsis revealed bacterial cystitis, which may have been caused by paresis and urinary retention identified in these animals.

Animals in the SG and SGCT groups received treatment based on clinical symptoms and laboratory findings, which consisted on antipyretics, vitamin complexes, antibiotics, and intravenous fluids according to electrolyte imbalance. These therapies are indicated for the treatment of canine distemper to control the clinical symptoms of CDV infection (Sherding, 2008; Nelson and Couto, 2010; Curti et al., 2012). MSCs derived from the fetal canine olfactory epithelium $\left(1.0 \times 10^{6} / \mathrm{kg}\right)$, were intravenously transplanted through the cephalic vein to SGCT animals. This technique requires a large volume of cells because some cells are lost at the first passage through the lungs; therefore, there is a risk of pulmonary thromboembolism due to the large cell volume (Fischer et al., 2009). However, in this study, no adverse effects were observed during or after MSC transplantation. Conversely, intravenous transplantation enables the activation of paracrine, anti-inflammatory, immunomodulatory, and anti-fibrotic mechanisms, which are important in stem cell-based therapies (Deak et al., 2010; Quimby et al., 2013). A high mortality rate was observed in both groups, which may be related to acute clinical and neurological symptoms and to the severity of the disease. This is thought to be reserved in the initial phases and severe in the advanced and neurological phases, where irreversible consequences or animal death may occur (Correa and Correa, 1979).

In conclusion, the protocol used in the present study using canine olfactory epithelial cells is not effective for dogs with CDV infection due to the severity of the systemic and neurological presentation. We suggest that further studies using infected animals in the chronic phase of the disease are needed due to the stabilization of the clinical and cellular characteristics of stem cells, which can initiate a potential systemic inflammatory process to control canine distemper virus.

\section{Conflicts of interest}

The authors declare no conflict of interest. 


\section{ACKNOWLEDGMENTS}

Research supported by Coordenação de Aperfeiçoamento de Pessoal de Nível Superior (CAPES). The authors would like to thank Aline Fernanda de Souza and Naira Pieri for her helpful feedback throughout the Project.

\section{REFERENCES}

Alcalde R, Kogika MM, Fortunato VA, Coelho BMP, et al. (2013). Canine distemper virus: detection of viral RNA by Nested RT-PCR in dogs with clinical diagnosis. Braz. J. Vet. Res. Anim. Sci. 50: 74-76. http://dx.doi.org/10.11606/ issn.2318-3659.v50i1p 74-76

Alves FR (2009) Avaliação da cultura de células-tronco do epitélio olfatório de cães sem raça definida (Canis familiares Linnaeus, 1758). Doctoral thesis.Universidade de São Paulo, São Paulo.

Alves FR, Santos TC, Freiberger S, Ambrósio CE, et al. (2007). Dinâmica dos precursores celulares do epitélio olfatório de cães sem raça definida: um estudo imunohistoquímico e ultra-estrutural. Pesq. Vet. Bras. 27: 388-392. http:// dx.doi.org/10.1590/S0100-736X2007000900006

Bydlowski SP, Debes AA, Maselli LMF and Janz FL (2009). Características biológicas das células-tronco mesenquimais. Rev. Bras. Hematol. Hemoter. 31 (Suppl 1): 25-35. http://dx.doi.org/10.1590/S1516-84842009005000038

Carvalho OV, Botelho CV, Ferreira CGT, Scherer PO, et al. (2012). Immunopathogenic and neurological mechanisms of canine distemper virus. Adv. Virol. 2012: 163860. http://dx.doi.org/10.1155/2012/163860

Correa WM and Correa CNM (1979). Enfermidades infecciosas dos mamíferos domésticos. 1 ed., J. M. Varela Livros, São Paulo, SP, Brazil, 823.

Cottrell WO, Keel MK, Brooks JW, Mead DG, et al. (2013). First report of clinical disease associated with canine distemper virus infection in a wild black bear (Ursus americana). J. Wildl. Dis. 49: 1024-1027. http://dx.doi.org/10.7589/2013$\underline{02-027}$

Curti MC, Arias MVB, Zanutto MS, Dias MBMC, et al. (2012). Cinomose canina: revisão de literatura. Med. Vet. 6: 32-40.

Deak E, Rüster B, Keller L, Eckert K, et al. (2010). Suspension medium influences interaction of mesenchymal stromal cells with endothelium and pulmonary toxicity after transplantation in mice. Cytotherapy 12: 260-264. http://dx.doi. org $/ 10.3109 / 14653240903401840$

Di Francesco CE, Di Francesco D, Di Martino B, Speranza R, et al. (2012). Detection by hemi-nested reverse transcription polymerase chain reaction and genetic characterization of wild type strains of Canine distemper virus in suspected infected dogs. J. Vet. Diagn. Invest. 24: 107-115. http://dx.doi.org/10.1177/1040638711425700

Dominici M, Le Blanc K, Mueller I, Slaper-Cortenbach I, et al. (2006). Minimal criteria for defining multipotent mesenchymal stromal cells. The International Society for Cellular Therapy position statement. Cytotherapy 8: 315317. http://dx.doi.org/10.1080/14653240600855905

Edamura K, Nakano R, Fujimoto K, Teshima K, et al. (2014). Effects of cryopreservation on the cell viability, proliferative capacity and neuronal differentiation potential of canine bone marrow stromal cells. J. Vet. Med. Sci. 76: 573-577. http://dx.doi.org/10.1292/jvms.13-0296

Elia G, Belloli C, Cirone F, Lucente MS, et al. (2008). In vitro efficacy of ribavirin against canine distemper virus. Antiviral Res. 77: 108-113. http://dx.doi.org/10.1016/j.antiviral.2007.09.004

Fischer UM, Harting MT, Jimenez F, Monzon-Posadas WO, et al. (2009). Pulmonary passage is a major obstacle for intravenous stem cell delivery: the pulmonary first-pass effect. Stem Cells Dev. 18: 683-692. http://dx.doi. org $/ 10.1089 / \mathrm{scd} .2008 .0253$

Gebara CMS, Wosiacki SR, Negrão FJ, De Oliveira DB, et al. (2004). Detecção do gene da nucleoproteína do vírus da cinomose canina por RT-PCR em urina de cães com sinais clínicos da cinomose. Arq. Bras. Med. Vet. Zootec. 56: 480-487. http://dx.doi.org/10.1590/S0102-09352004000400009

Granger N, Blamires H, Franklin RJM and Jeffery ND (2012). Autologous olfactory mucosal cell transplants in clinical spinal cord injury: a randomized double-blinded trial in a canine translational model. Brain 135: 3227-3237. http:// dx.doi.org/10.1093/brain/aws 268

Lempp C, Spitzbarth I, Puff C, Cana A, et al. (2014). New aspects of the pathogenesis of canine distemper leukoencephalitis. Viruses 6: 2571-2601. http://dx.doi.org/10.3390/v6072571

Lockhart JA (1971). An interpretation of cell growth curves. Plant Physiol. 48: 245-248. http://dx.doi.org/10.1104/ pp.48.3.245

Mangia SH and Paes AS (2008). Neuropatologia da cinomose. Vet. Zootec. 15: 416-427.

Genetics and Molecular Research 15 (2): gmr.15028310

CFUNPEC-RP www.funpecrp.com.br 
Mangia SH, Moraes LF, Takahira RK, Motta RG, et al. (2014). Efeitos colaterais do uso da ribavirina, prednisona e DMSO em cães naturalmente infectados pelo vírus da cinomose. Pesqui. Vet. Bras. 34: 449-454. http://dx.doi.org/10.1590/ $\underline{\text { S0100-736X2014000500011 }}$

Martella V, Elia G and Buonavoglia C (2008). Canine distemper virus. Vet. Clin. North Am. Small Anim. Pract. 38: 787797, vii-viii. http://dx.doi.org/10.1016/j.cvsm.2008.02.007

Marti LC, Ribeiro AAF and Hamerschlak N (2011). Immunomodulatory effect of mesenchymal stem cells. Einstein 9: 224-228. http://dx.doi.org/10.1590/S1679-45082011RW1843

McCandlish IAP (2001). Infecções específicas caninas. In: Dunn JK. Tratado de medicina de pequenos animais. 1 ed, Editora Roca, São Paulo. pp. 915-952.

Mendonça RB, Pagani FF and Moreira de Souza A (2000). Respostas hematológicas em cães naturalmente infectados pelo vírus da cinomose: estudo retrospectivo de casos. Rev. Bras. Cienc. Vet. 7: 114.

Nardi NB and da Silva Meirelles L (2006). Mesenchymal stem cells: isolation, in vitro expansion and characterization. Handbook Exp. Pharmacol. 174: 249-282. http://dx.doi.org/10.1007/3-540-31265-X_11

Negrão FJ, Alfieri AA and Alfieri AF (2007). Avaliação da urina e de leucócitos como amostras biológicas para a detecção ante mortem do vírus da cinomose canina por RT-PCR em cães naturalmente infectados. Arq. Bras. Med. Vet. Zootec. 59: 253-257. http://dx.doi.org/10.1590/S0102-09352007000100042

Nelson RW and Couto CG (2010). Medicina interna de pequenos animais. 4 ed, Elsevier, Rio de Janeiro, 1468 p.

Nery AA, Nascimento IC, Glaser T, Bassaneze V, et al. (2013). Human mesenchymal stem cells: from immunophenotyping by flow cytometry to clinical applications. Cytometry A 83: 48-61. http://dx.doi.org/10.1002/cyto.a.22205

Qui W, Zheng Y, Zhang S, Fan Q, et al. (2011). Canine distemper outbreak in Rhesus nonkeys, China. Emerg. Infect. Dis. 7: 1541-1543.

Quimby JM, Webb TL, Habenicht LM and Dow SW (2013). Safety and efficacy of intravenous infusion of allogeneic cryopreserved mesenchymal stem cells for treatment of chronic kidney disease in cats: results of three sequential pilot studies. Stem Cell Res. Ther. 4: 48. http://dx.doi.org/10.1186/scrt198

Sampaio RV, Chiaratti MR, Santos DCN, Bressan FF, et al. (2015). Generation of bovine (Bos indicus) and buffalo (Bubalus bubalis) adipose tissue derived stem cells: isolation, characterization, and multipotentiality. Genet. Mol. Res. 14: 53-62. http://dx.doi.org/10.4238/2015.January.15.7

Sánchez-Berná I, Santiago-Díaz C and Jiménez-Alonso J (2015). Immunomodulatory properties of stem mesenchymal cells in autoimmune diseases. Med. Clin. (Barc.) 144: 88-91.

Sherding RG (2008) Cinomose canina. In: Birchard, SJ, Sherding, RG. Manual Sanders-Clínica de pequenos animais. 3 ed, Editora Roca, São Paulo, 2048 p.

Silva ING, Guedes MIF, Rocha MFG, Medeiros CMO, et al. (2005). Perfil hematológico e avaliação eletroforética das proteínas séricas de cães com cinomose. Arq. Bras. Med. Vet. Zootec. 57: 136-139. http://dx.doi.org/10.1590/S0102$\underline{09352005000100019}$

Sonne L, Oliveira EC, Pescador CA, Santos AS, et al. (2009). Achados patológicos e imuno-histoquímicos em cães infectados naturalmente pelo vírus da cinomose canina. Pesqui. Vet. Bras. 29: 145-149. http://dx.doi.org/10.1590/ S0100-736X2009000200010

Trejo-Avila LM, Morales-Martínez ME, Ricque-Marie D, Cruz-Suarez LE, et al. (2014). In vitro anti-canine distemper virus activity of fucoidan extracted from the brown alga Cladosiphon okamuranus. Virusdisease 25: 474-480. http:// dx.doi.org/10.1007/s13337-014-0228-6

Ueda FS, Penha GA, Suzuki EY and Filadelpho AL (2008). Acupuntura e cinomose: revisão de literatura. Rev. Cient. Elet. Med. Vet. 10: 1-7.

Vidane AS, Souza AF, Sampaio RV, Bressan FF, et al. (2014). Cat amniotic membrane multipotent cells are nontumorigenic and are safe for use in cell transplantation. Stem Cells Cloning 7: 71-78.

Wenceslau CV, Miglino MA, Martins DS, Ambrósio CE, et al. (2011). Mesenchymal progenitor cells from canine fetal tissues: yolk sac, liver, and bone marrow. Tissue Eng. Part A 17: 2165-2176. http://dx.doi.org/10.1089/ten. tea. 2010.0678 